\title{
Principal Component and Multivariate Analysis of Milk Long-Chain Fatty Acid Composition During Diet-Induced Milk Fat Depression
}

\author{
A. K. G. Kadegowda, L. S. Piperova, and R. A. Erdman ${ }^{1}$ \\ Animal and Avian Sciences Department, University of Maryland, College Park 20742
}

\begin{abstract}
The objective of this study was to assess the relationship between individual milk fatty acids (FA) and dietinduced milk fat depression (MFD) using principal component analysis (PCA) and multivariate analysis (MA). Cow treatment observations $(\mathrm{n}=63)$ from 3 published feeding experiments with lactating dairy cows were used in the analyses. In the PCA, principal component loading plots 1 (PC1) and 2 (PC2) described 55.9\% of the total variation in milk FA and fat concentrations. Saturated FA (14:0, 16:0, and 17:0) and milk fat percentage showed negative loading for PC1. Trans-18:1 isomers (trans- $6+7+8$ to trans-15), trans-7, cis-9 conjugated linoleic acid (CLA), and trans-10, cis-12 CLA showed positive (opposite) loading, suggesting a negative relationship between these isomers and milk fat percentage. Cis-11, trans-13 CLA and cis-9, trans-11 CLA were associated with the PC2 axes (neutral), indicating that they were not associated with MFD. Multivariate analysis with milk fat percentage as the dependent variable and individual PC1 positive loading variables showed a breakpoint relationship for trans6+7+8-, trans-9-, trans-10-, and trans-13+14-18:1 and a linear relationship for trans-11-, trans-12-, trans-1518:1, trans-10, cis-12 CLA, and trans-7, cis-9 CLA. Subsequent MA was conducted on 41 treatment means from 12 independent experiments from the literature, in which concentrations of trans-6+7+8-, trans-9-, trans10-, and trans-11-18:1, and cis-9 trans;-11, and trans10, cis-12 CLA were reported. Significant negative effects of trans-9-18:1, trans-10-18:1, and trans-10, cis12 CLA on milk fat percentage were observed. In this study, the PCA and MA showed that among trans-18:1 isomers, trans-10-18:1 was the most negatively correlated to milk fat percentage. However, the threshold concentration related to maximum MFD indicated that the relative potency was greatest for trans $-6+7+8$ - and lowest for trans-10-18:1. These results suggested that
\end{abstract}

Received April 6, 2007.

Accepted October 9, 2007.

${ }^{1}$ Corresponding author: erdman@umd.edu trans $-6+7+8-18: 1$ might be more important than trans10-18:1 in MFD. Principal component analysis also showed that trans-10, cis-12 and trans-7, cis-9 CLA were the isomers most negatively correlated to milk fat percentage, implying a possible role of trans-7, cis-9 CLA in MFD. Additional experiments are needed to establish whether trans-7-18:1 is involved in MFD or that its effects are mediated via the endogenously synthesized trans-7, cis-9 CLA.

Key words: milk fat depression, fatty acid, principal component analysis, multivariate analysis

\section{INTRODUCTION}

It has been demonstrated that conjugated linoleic acid (CLA) and trans-18:1 fatty acids (FA) arising from incomplete rumen biohydrogenation of dietary polyunsaturated fatty acids (PUFA) can markedly alter milk fat synthesis. Numerous studies have shown that concentrations of trans-18:1 FA or CLA can be increased in milk via dietary means (Griinari et al., 1998; Piperova et al., 2000; Peterson et al., 2003) or abomasal infusion (Gaynor et al., 1994; Romo et al., 1996; Chouinard et al., 1999) and can cause reduction of milk fat concentration. Examination of the isomer profile of trans-18:1 FA (Griinari et al., 1998) and CLA (Griinari and Bauman., 1999) indicated that increases in ruminally derived trans-10-containing 18:1 and 18:2 isomers in milk were more closely associated with milk fat depression (MFD) than the general increase in total trans-18:1 or CLA. We were able to demonstrate that abomasal infusion of partially hydrogenated vegetable oil (Gaynor et al., 1994; Romo et al., 1996) or diets supplemented with Ca salts of trans-18:1 containing isomers from trans-(t)6 to t16 (Piperova et al., 2004) can cause MFD. However, when individual trans-18:1 isomers, including t9- (Rindsig and Schultz, 1974), t11-, and t12- (Griinari et al., 2000) were postruminally infused, milk fat was not affected. Although high concentrations of t10-18:1 are typically observed in the milk fat of lactating cows fed MFD diets (Piperova et al., 2000; Peterson et al., 2003; Loor et al., 2004), abomasal infusion of $40 \mathrm{~g} / \mathrm{d}$ of t10-18:1 was not effective in reducing milk fat percentage in lactating cows (Lock et al., 
Table 1. Details of the experimental data used in the principal components analysis

\begin{tabular}{lccc}
\hline Reference & $\begin{array}{c}\text { Observations/ } \\
\text { treatment }\end{array}$ & $\begin{array}{c}\text { Total } \\
\text { observations }\end{array}$ & Treatments \\
\hline Piperova et al., 2000 & 11 & 22 & $\begin{array}{c}\text { Control diet (forage:concentrate 60:40); MFD }{ }^{1} \text { diet } \\
\text { (25\% forage and 70\% concentrate with 5\% soybean oil). }\end{array}$ \\
Piperova et al., 2002 & 4 & 16 & $\begin{array}{c}\text { High forage (60\% forage) with or without buffer addition; } \\
\text { Low forage (25\% forage) with or without buffer addition. } \\
\text { Control; 100, 200, or } 400 \text { g of Ca-tFA }{ }^{2} \text { supplement; } \\
\text { 100 g of Ca-conjugated linoleic acid supplement. }\end{array}$ \\
\hline
\end{tabular}

${ }^{1}$ Milk fat depression.

${ }^{2}$ Calcium salts of trans-18:1 fatty acids.

2007). Baumgard et al. (2000) provided convincing evidence that abomasal infusion of $10 \mathrm{cis}$-(c) 12 CLA inhibits milk fat synthesis. Nevertheless, in an earlier study, Chouinard et al. (1999) observed MFD in lactating cows abomasally infused with a CLA mixture lacking t10c12 CLA.

Feeding experiments have shown that the concentration of t10c12 CLA in milk does not always account for the degree of MFD (Peterson et al., 2003) and that reduction in milk fat concentration can occur without increases in t10c12 CLA in milk (Piperova et al., 2004; Loor et al., 2005a). The t8c10 CLA and c11t13 CLA isomers usually present in lower concentrations in commercial CLA mixtures were examined by Perfield et al. (2004); they found no effect of these isomers on milk fat synthesis. These collective results suggest that there must be other biohydrogenation intermediates besides t10c12 CLA involved with MFD.

Multivariate analysis (MA) can be applied to visualize the multidimensionality of the data to identify underlying variables that may contribute to dietary MFD. Principal component analysis (PCA) is a multivariate technique that reduces the dimensionality of data by transforming a number of related variables into a set of uncorrelated variables, while retaining as much variation as possible. The transformed new variables, referred to as principal components (PC), are the linear combinations of the original variables. The first PC (PC1) accounts for the maximum variability, whereas the remaining $\mathrm{PC}(\mathrm{PC} 2, \mathrm{PC} 3, \ldots \mathrm{PCn}, \mathrm{n}=$ number of variables) account for the remaining variability in the data. Each PC is independent and orthogonal to the other. Generally, only the first few PC describe the majority of total variation in the data as indicated by the Eigen values (Kent and Coker, 1992; Jolliffe, 2002). As a means to potentially identify individual FA effects, the objective of this study was to assess the relationship between milk FA and diet-induced MFD using PCA and MA.

\section{MATERIALS AND METHODS}

\section{Experimental Design and Diets}

Individual cow-within-treatment observations $(\mathrm{n}=$ 63) from 3 published feeding experiments conducted at the University of Maryland (Piperova et al., 2000, 2002, 2004 ) with lactating dairy cows were used in this analysis. The studies comprised diets with different forageto-concentrate ratios (with or without vegetable oil or buffer addition) and diets supplemented with Ca salts of trans-18:1 FA or CLA. Diets were formulated to meet NRC (2001) requirements for milk production at $40 \mathrm{~kg} /$ $\mathrm{d}$ and $3.5 \%$ fat. Details of the experiments used in the study are presented in Table 1 . In each experiment, cows were housed in individual stalls and fed individually. Forage and concentrate DM was measured weekly, and the TMR was adjusted accordingly to maintain constant forage-to-concentrate ratio on a DM basis during the experiment. Milk production was recorded at each milking. At the end of each experimental period, milk samples from 6 consecutive milkings were collected and composited for FA analysis.

\section{Analytical Methods}

The FA composition of milk samples and Ca-trans FA and Ca-CLA supplements was determined using FA methyl esters (FAME) prepared by mild transesterification with $0.04 M \mathrm{H}_{2} \mathrm{SO}_{4}$ in methanol, at room temperature, using GLC conditions previously described (Piperova et al., 2000). Trans-18:1 concentration in milk and isomer distribution were determined by a combination of preparative $\mathrm{Ag}^{+}$-thin layer chromatography and GLC analysis (Piperova et al., 2000). ArgentationHPLC was used to determine CLA isomer distribution patterns (Piperova et al., 2000).

\section{Statistical Analysis}

Relationships between milk FA were evaluated from PCA loading plots, based on the correlation matrix, 
Table 2. Correlation coefficients for the milk fatty acids (\% of total fatty acids) from inidividual cow observations reported by Piperova et al. $(2000,2002,2004)^{1}$

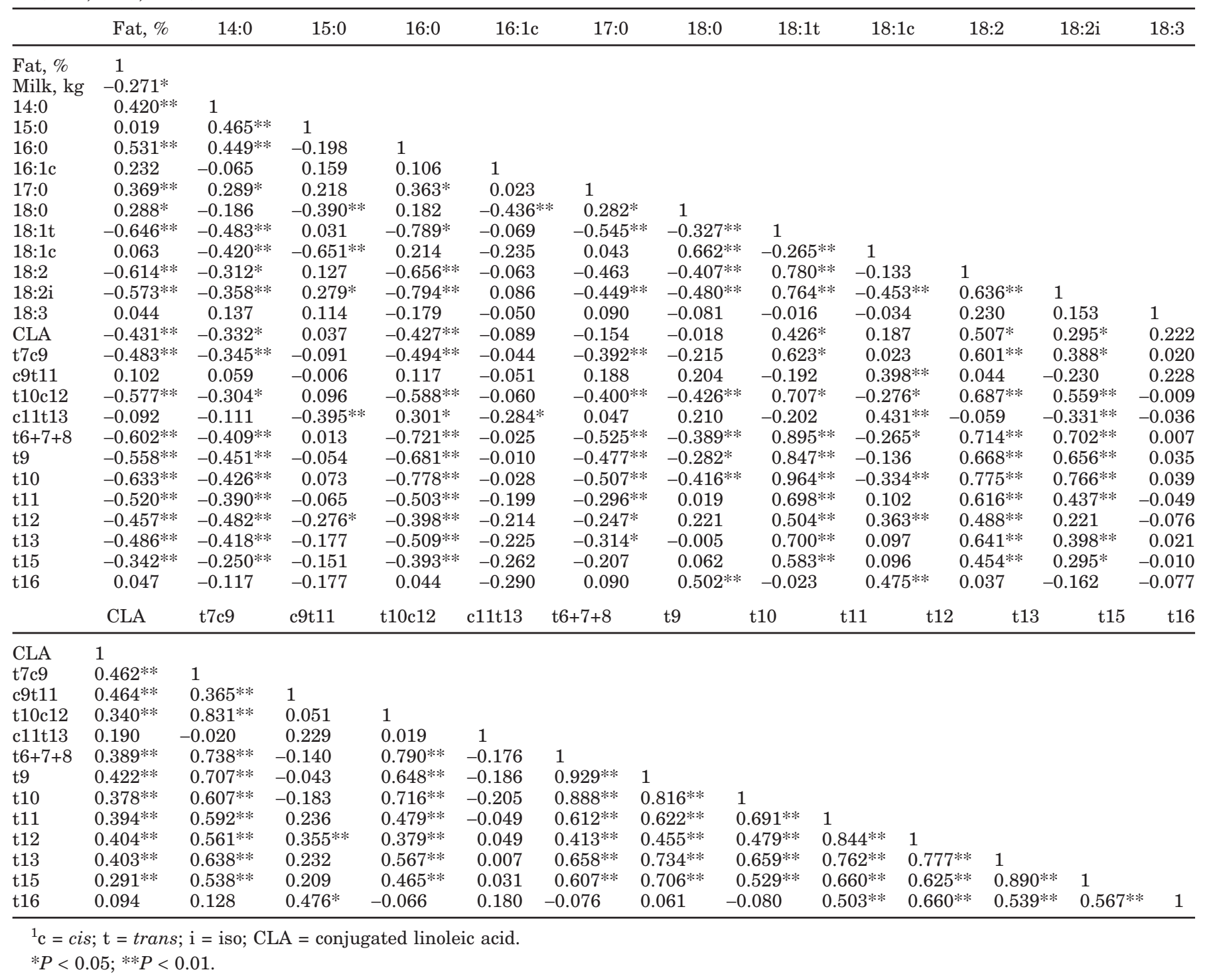

using XLSTAT software (XLSTAT Pro 7.5.2 for Windows, Addinsoft, New York, NY). Relationships between individual milk FA concentrations (\% of total FAME) and fat percentage on individual cow treatment observations were analyzed using the NLmixed procedure (SAS Institute, 2000) with a breakpoint or simple linear regression model analysis depending on the best fit for each individual FA. Fatty acids were analyzed only if they were present in all experiments. Data for short-chain FA were available in only 1 of the 3 experiments and were not included in the analysis. The breakpoint analysis used the following model: $\mathrm{Y}=\mathrm{b}_{0}+$ $\left(b_{1} \times X\right)+E_{n}$; if $X \leq$ breakpoint, then $Y=b_{2}+E_{n}$, where $\mathrm{Y}=$ milk fat percentage; $\mathrm{b}_{0}$ and $\mathrm{b}_{2}=$ intercept values for regression lines 1 and 2 , respectively; $b_{1}=$ slope of regression line 1 ; and $\mathrm{E}_{\mathrm{n}}=$ experiment effect.
The breakpoint in this analysis is the concentration of FA, where regression lines 1 and 2 intercept.

Subsequent MA were conducted on treatment means ( $\mathrm{n}=41$ ) from 12 independently published experiments (Donovan et al., 2000; Loor et al., 2002, 2003, 2005a,b; Peterson et al., 2002b, 2003; AbuGhazaleh et al., 2003, 2004; Shingfield et al., 2003; Loor and Herbein, 2003; Selberg et al., 2004) that reported concentrations of t6+7+8-, t9-, t10-, t11-18:1, and c9t11 and t10c12 CLA isomers in milk of lactating cows.

\section{RESULTS}

Correlation coefficients between the variables are presented in Table 2. The 14:0, 16:0, 17:0 and 18:0 saturated FA were positively correlated $(P<0.001, P$ 


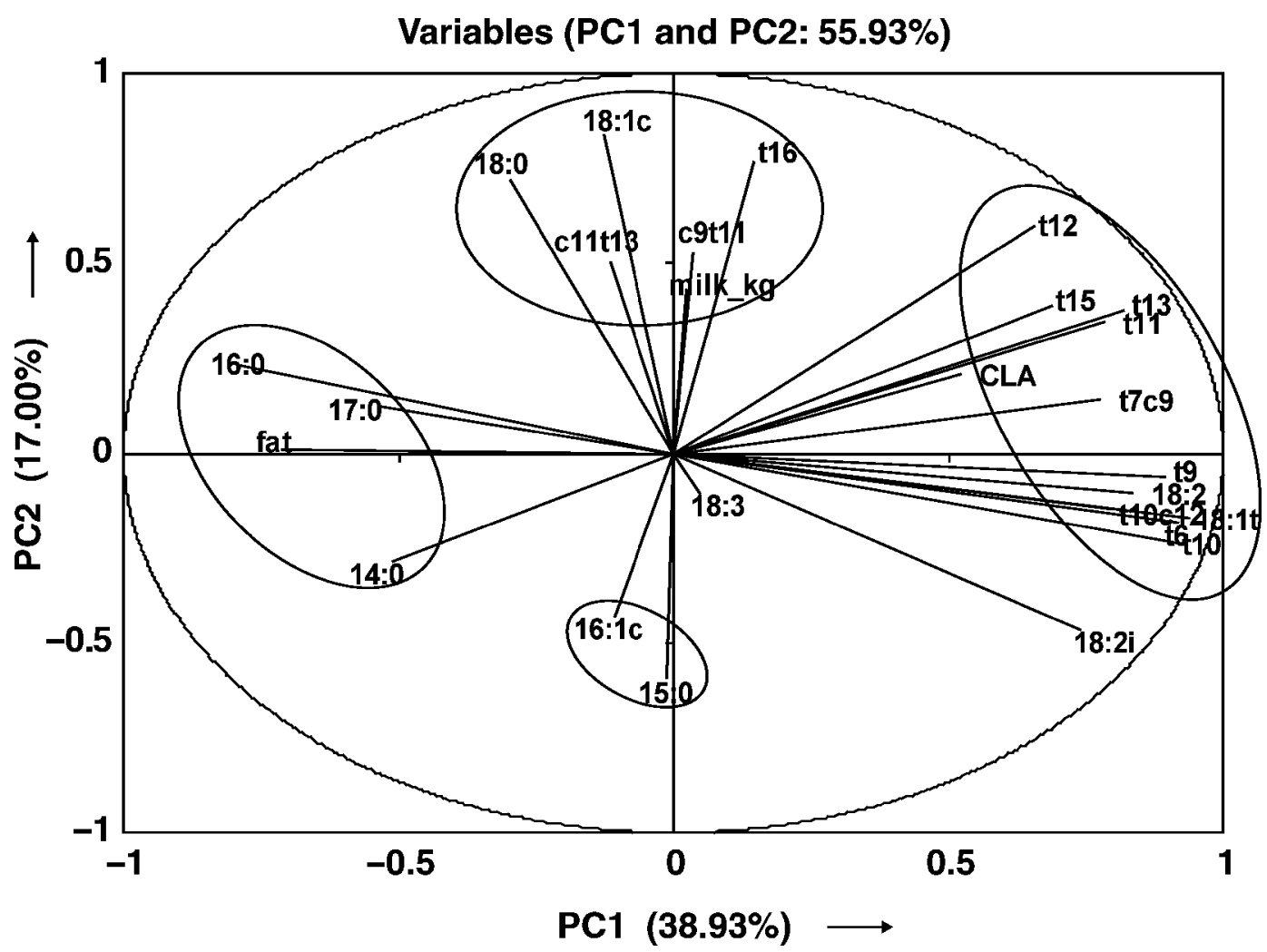

Figure 1. Loading plot describing the relationship among milk fatty acids (FA) derived from a principal component analysis based on proportions (\% of total fatty acids) of C14 to C18 FA in milk from 3 experiments ( $=63$ ). Four clusters of FA were distinguished. Trans18:1 isomers (except trans-16-18:1), total conjugated linoleic acid (CLA), trans-10, cis-12 CLA and trans-7, cis-9 CLA were loaded opposite (negatively related) to milk fat percentage, whereas saturated FA (14:0, 16:0, and 17:0) were loaded with milk fat percentage. $t=$ trans; $\mathrm{c}=$ cis.

$<0.001, P<0.03$, and $P<0.02$, respectively) to milk fat percentage. Conversely, 14:0, 16:0, and 17:0 FA were negatively correlated to trans-18:1 and CLA isomers, with the exception of c9t11 CLA, c11t13 CLA, t16-18:1, and t15-18:1 (for 17:0). The 18:0 was associated negatively to trans-18:1, t6+7+8-, t10-18:1, and t10c12 CLA. Total trans-18:1 and individual trans-18:1 isomers (except t16-18:1) were negatively correlated to milk fat concentration $(P<0.001)$. The t7c9 CLA and t10c12 CLA isomers were significantly $(P<0.001)$ negatively correlated to milk fat concentration, contributing to the negative correlation observed for the total CLA. Linoleic acid and nonconjugated 18:2 isomers (18:2i) were negatively correlated with milk fat and were positively correlated with CLA and trans-18:1 isomers with the exception of c9t11 CLA, c11t13 CLA, and t16-18:1. Among the CLA, t7c9 CLA and t10c12 CLA isomers were highly correlated $(\mathrm{r}=0.831 ; P<0.001)$ to each other and both were positively correlated $(P<0.001)$ to trans-18:1 isomers (t6+7+8 to t-15). Cis-9, trans-11 CLA was positively correlated to t7c9 CLA $(\mathrm{r}=0.365, P<0.03)$, t11$18: 1(\mathrm{r}=0.236, P<0.06)$, and $\mathrm{t} 12-18: 1(\mathrm{r}=0.355, P<$
$0.01)$, whereas c11t13 CLA was positively correlated to 16:0 $(\mathrm{r}=0.18)$. Trans-18:1 isomers, with the exception of t16, were highly correlated $(P<0.001)$ to each other and to t7c9 CLA and t10c12 CLA.

In the PCA, PC1 and PC2 described $55.93 \%$ of the total variation in milk FA and fat concentration across the 3 experiments (Table 3). Principal components 1 and 2 had Eigen vectors of 10.12 and 4.42 describing 38.9 and $17 \%$ of the total variance, respectively. Eigen vectors are the coefficients of loadings that explain if all variables in the data are described by the PCA. The Eigen vectors for PC1 and PC2 (Table 4) showed that, except for 18:3, all FA were described by either PC1 or PC2, or by both.

The position of individual FA in the loading plot defined their relationship to milk fat percentage (Figure 1). Four clusters of FA were identified on the loading plot: cluster 1 , consisting of 14:0, 16:0, and 17:0, was positively correlated to milk fat $(P<0.05$, Table 3$)$; cluster 2, consisting of trans-18:1 isomers ( $\mathrm{t} 6+7+8$ to t15), total CLA, t7c9, and t10c12 CLA, loaded opposite to milk fat percentage, showing a strong negative corre- 


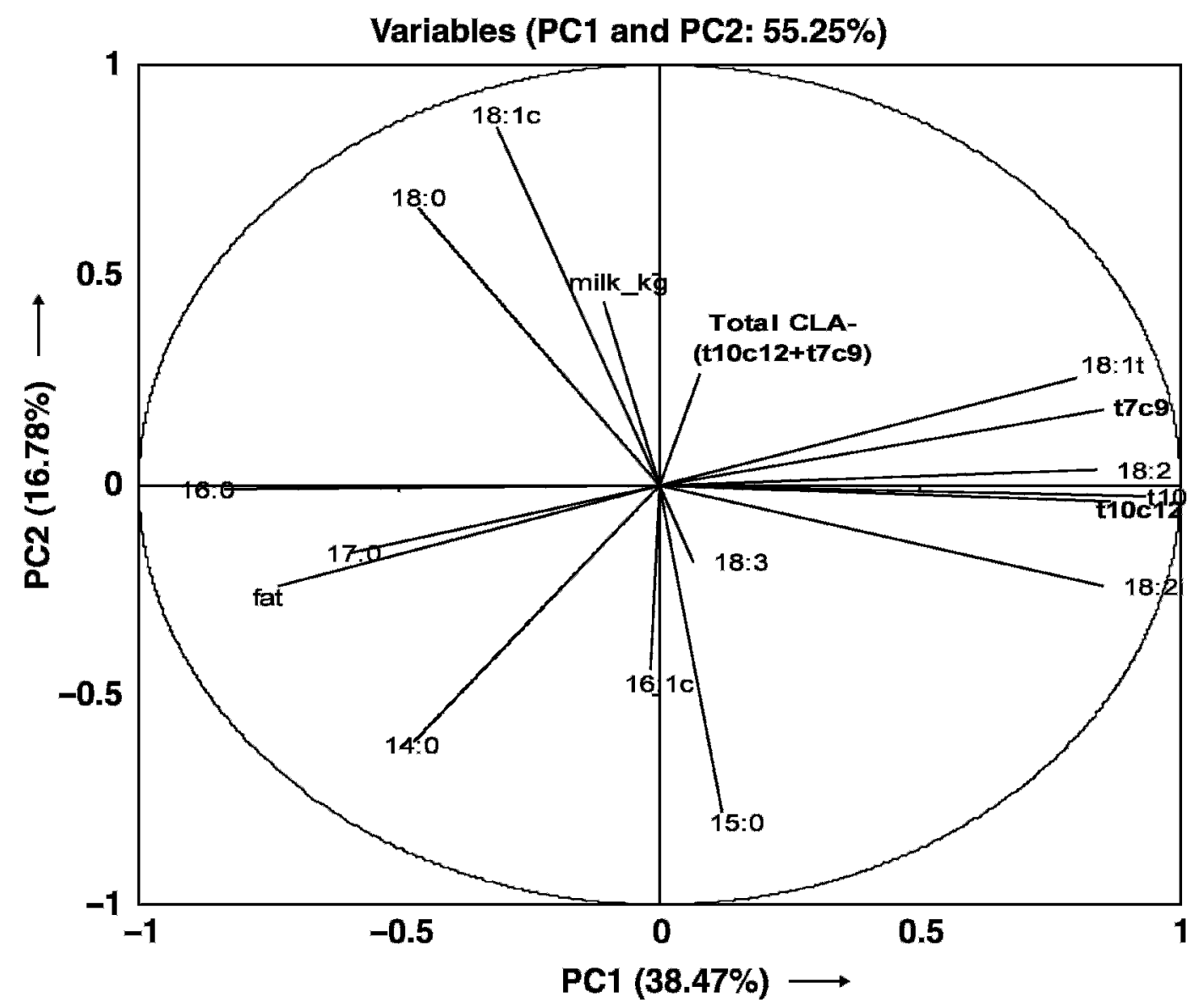

Figure 2. Loading plot describing the relationship among milk conjugated linoleic acid (CLA) isomers derived from a principal component (PC) analysis, based on the proportions (\% of total fatty acids) of CLA isomers. The position of total CLA shifted closer to PC2 (neutral) axis when trans-10, cis-12 CLA and trans-7, cis-9 CLA were subtracted. $\mathrm{t}=$ trans; $\mathrm{c}=$ cis.

lation (Table 2); cluster 3, including 15:0 and 16:1; and cluster 4, consisting of 18:0, c18:1, t16-18:1, and c9t11, c11t13 CLA, were both associated with the PC2 neutral axis suggesting no relationship, either positive or negative, with milk fat percentage. Finally, linolenic acid (18:3), positioned close to the origin of the plot, was not related to any of the $\mathrm{PC}$.

To further elucidate the relative importance of each CLA isomer to MFD, individual CLA isomers were subtracted from the total CLA concentration to determine their effects on the position of the remaining CLA on the loading plot (data not shown). Total CLA, t10c12, and t7c9 CLA isomers were inversely correlated to milk fat percentage emphasizing their involvement in MFD (Figure 1, Table 2). Subtraction of either t7c9 CLA or t10c12 CLA from total CLA did not change the position of the remaining CLA isomers to the PC1 axis (data not shown). However, when both t7c9 CLA and t10c12 CLA isomers were subtracted from total CLA, the remaining CLA isomers were positioned closer to the neutral PC2 axis (Figure 2). The c9t11 CLA and c11t13
CLA were not associated with changes in milk fat percentage. Because of the positive correlation between all trans-18:1 isomers, subtraction of individual isomers from total trans-18:1 did not change their position on the loading plot (data not shown).

Multivariate analysis on PC1 positively loaded variables showed a breakpoint relationship for $t 6+7+8$, t9-, t10-, and t13+14-18:1 isomers and linear relationship for t11-, t12- t15-18:1, t10c12 CLA, and t7c9 CLA with milk fat percentage (Figure 3, "a" panels). Subsequent MA of the independently gathered literature means showed a breakpoint relationship only for t1018:1 and a linear relationship among t6+7+8-, t9-, t1118:1, and t10c12 CLA, and milk fat percentage (Figure 3 , "b" panels).

\section{DISCUSSION}

The PCA and results from the correlation matrix confirmed previous reports (Bradford and Allen, 2004; Loor et al., 2005a) that trans-18:1 and CLA isomers were 

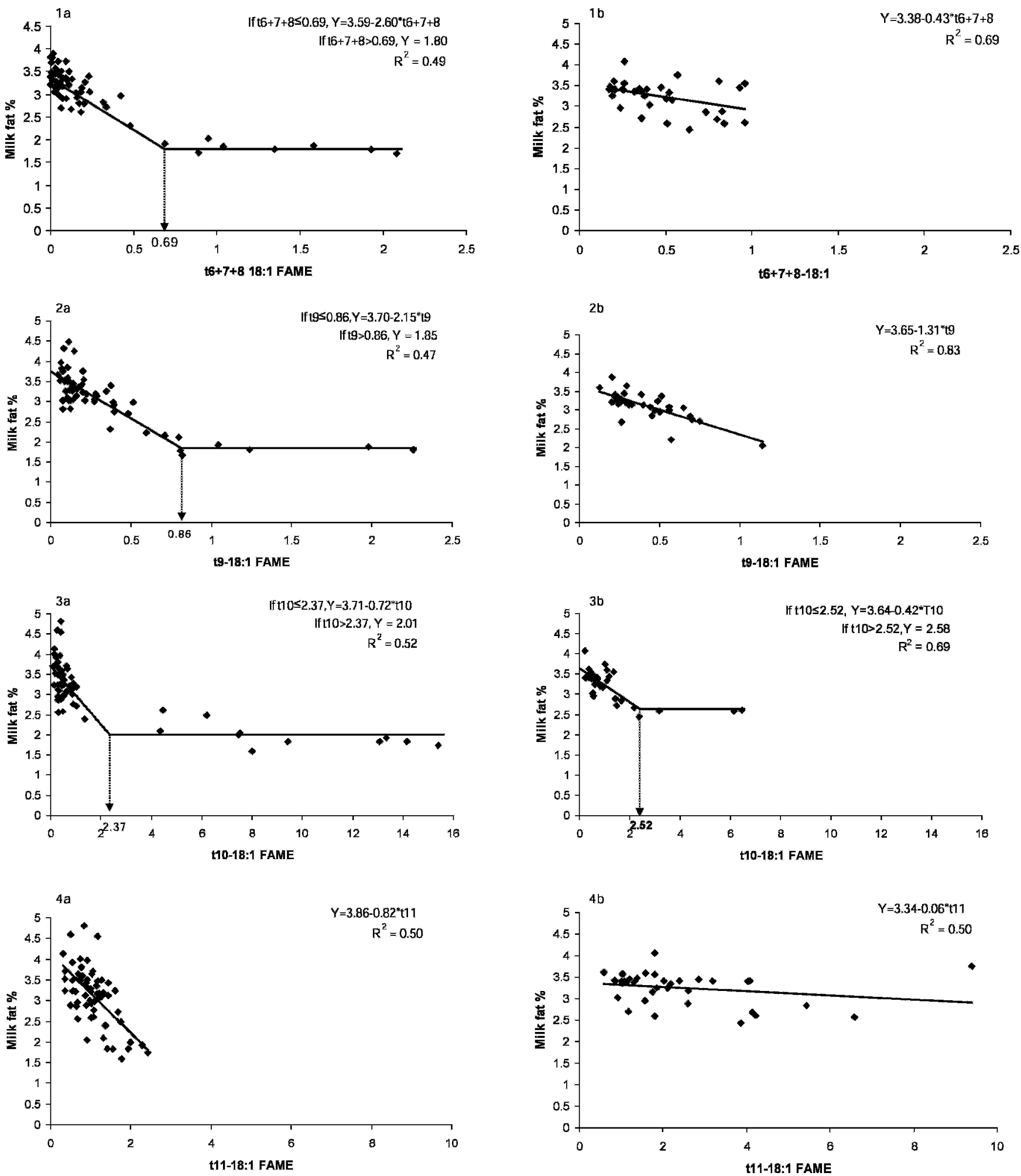

Figure 3. Relationship between milk fat percentage and fatty acid (FA) isomers, as explained by multivariate analysis. The data points in the "a" panels are individual observations from the experiments reported by Piperova et al. (2000; 2002; 2004). The breakpoint analysis fitted for trans-6+7+8-, trans-9-, trans-10-, and trans-13+14-18:1 (panels 1a, 2a, 3a, and 6a, respectively). A linear relationship was observed between the other FA isomers and milk fat percentage. The data points in "b" panels are reported means from the literature studies used. Only trans-10-18:1 (3b) fitted the breakpoint analysis. A linear relationship was observed between the other FA isomers and milk fat percentage. $\mathrm{t}=$ trans; $\mathrm{c}=$ cis; FAME $=$ fatty acid methyl esters; CLA = conjugated linoleic acid. 

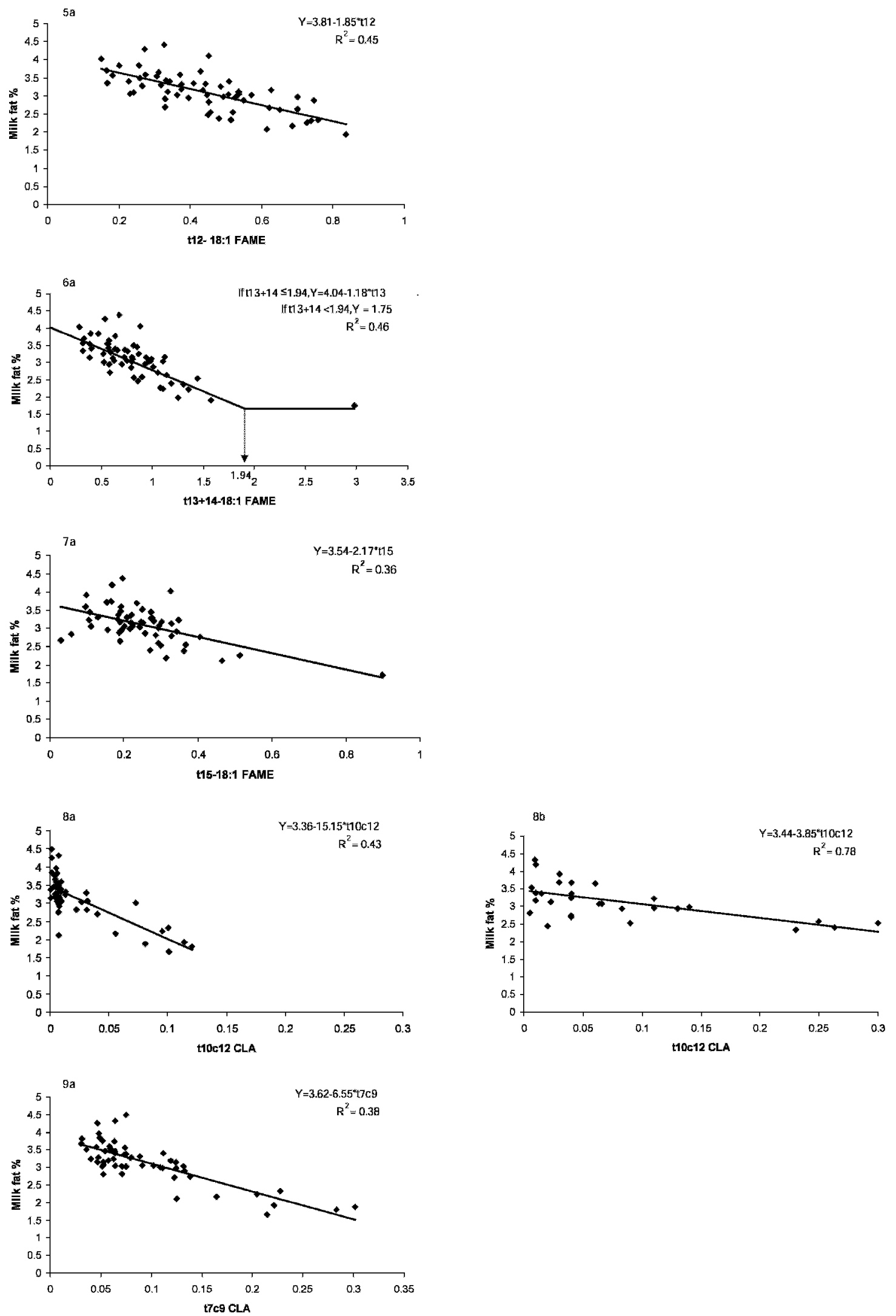

Figure 3 (continued). 
Table 3. Principal component Eigen values for principal components 1 and 2

\begin{tabular}{lccc}
\hline Principal component (PC) & Eigen value & $\begin{array}{c}\text { Proportion of } \\
\text { total variance }(\%)\end{array}$ & $\begin{array}{c}\text { Cumulative variance } \\
\text { proportion }(\%)\end{array}$ \\
\hline PC1 & 10.12 & 38.93 & 38.93 \\
PC2 & 4.42 & 17.00 & 55.93 \\
EPC3 to PC26 & 11.46 & 44.07 & 100.00 \\
\hline
\end{tabular}

negatively correlated to milk fat percentage. Although the results showed negative correlation of C18:2 to milk fat percentage, there is no evidence that C18:2 that escapes rumen biohydrogenation is directly involved in MFD. Studies (Gaynor et al., 1994; Romo et al., 1996) in lactating cows postruminally infused with fat mixtures containing similar amounts of C18:2 showed MFD only when the infusion mixture contained trans-18:1 FA. However, there is uncertainty as to the potential for individual trans-18:1 isomers to reduce milk fat concentration (Offer et al., 1999). Earlier experiments (Newbold et al., 1998) have found that change in milk fat concentration was related negatively to the change in t10-18:1 of milk but was not related to changes in t9and t11-18:1. Offer et al. (1999) reported significant negative correlations between concentration of fat in milk and proportions of t9-, t10-, and t11-18:1 isomers in milk. Loor et al. (2005a) reported that total trans-
18:1, t6+7+8-, t9-, t11-, and t12-18:1 were negatively correlated to concentrations of de novo FA in milk from lactating cows fed low or high concentrate diets with or without linseed oil. Increased concentration of $t 6+7+8$ 18:1 in milk was observed by others (Griinari et al., 1998; Piperova et al., 2000; Peterson et al., 2003) in cows fed MFD diets. Previously, Precht et al. (2002) suggested that $t 6+7+8-18: 1$ might be a key isomer in dietary MFD.

In the current study, t10-18:1 had the greatest negative correlation with milk fat percentage $(\mathrm{r}=0.633 ; P$ $<0.01$; Table 3) among all trans-18:1 isomers. Griinari et al. (1998) first suggested that the degree of MFD may be related to the proportions of individual trans18:1 isomers in milk fat and noted that t10-18:1 replaced t11-18:1 as the predominant trans-18:1 isomer in milk during MFD. High t10-18:1 concentration was consistently observed in lactating cows during dietary

Table 4. Coefficients of the loadings (Eigen vectors) for principal components (PC) PC1 and PC2

\begin{tabular}{|c|c|c|c|c|}
\hline Response variable $^{1}$ & $\mathrm{PC} 1$ & $\begin{array}{c}\text { Contribution for } \\
\text { PC1, \% }\end{array}$ & $\mathrm{PC} 2$ & $\begin{array}{c}\text { Contribution for } \\
\text { PC } 2, \%\end{array}$ \\
\hline Fat $\%$ & -0.224 & -9.73 & 0.003 & 0.19 \\
\hline Milk, kg & 0.007 & 0.30 & 0.204 & 12.60 \\
\hline \multicolumn{5}{|l|}{ Fatty acid } \\
\hline $14: 0$ & -0.160 & -6.90 & -0.136 & -8.40 \\
\hline $15: 0$ & -0.003 & -0.10 & -0.281 & -17.36 \\
\hline $16: 0$ & -0.248 & -10.80 & 0.109 & 6.73 \\
\hline $16: 1 c$ & -0.034 & -1.50 & -0.203 & -12.54 \\
\hline $17: 0$ & -0.168 & -7.50 & -0.059 & -3.64 \\
\hline 18:0 & -0.093 & -4.00 & 0.342 & 21.12 \\
\hline $18: 1 \mathrm{t}$ & 0.295 & 12.81 & -0.083 & -5.13 \\
\hline $18: 1 \mathrm{c}$ & -0.040 & -1.74 & 0.399 & 24.64 \\
\hline $18: 2$ & 0.262 & 11.38 & -0.049 & -3.02 \\
\hline $18: 2 \mathrm{i}$ & 0.232 & 10.08 & -0.223 & -13.77 \\
\hline $18: 3$ & 0.015 & 0.65 & -0.050 & -3.27 \\
\hline t7c9 & 0.244 & 10.60 & 0.066 & 4.08 \\
\hline c9t11 & 0.011 & 0.48 & 0.251 & 15.50 \\
\hline $\mathrm{t} 10 \mathrm{c} 12$ & 0.249 & 10.82 & -0.070 & -4.32 \\
\hline c11t13 & -0.037 & 1.60 & 0.238 & 14.70 \\
\hline \multicolumn{5}{|l|}{ Trans fatty acids } \\
\hline $\mathrm{t} 6+7+8$ & 0.288 & 12.51 & -0.088 & -5.44 \\
\hline t9 & 0.281 & 12.21 & -0.030 & -1.85 \\
\hline $\mathrm{t} 10$ & 0.289 & 12.55 & -0.113 & -6.98 \\
\hline $\mathrm{t} 11$ & 0.246 & 10.69 & 0.163 & 10.07 \\
\hline $\mathrm{t} 12$ & 0.206 & 8.95 & 0.285 & 17.60 \\
\hline $\mathrm{t} 13$ & 0.257 & 11.16 & 0.179 & 11.06 \\
\hline $\mathrm{t} 15$ & 0.217 & 9.43 & 0.185 & 11.43 \\
\hline $\mathrm{t} 16$ & 0.045 & 1.95 & 0.363 & 22.42 \\
\hline Total loadings (absolute) & 2.302 & 100.00 & 1.619 & 100.00 \\
\hline
\end{tabular}


MFD (Piperova et al., 2000; Peterson et al., 2003; Loor et al., 2004). However, during dietary-induced MFD, both t10-18:1 and t10c12 CLA increased simultaneously, making it difficult to determine if t10-18:1 had an effect on milk fat synthesis that was independent of t10c12 CLA effects. Shingfield et al. (2006) showed that 0.74 of the variation in milk fat concentration of lactating cows fed corn silage-based diets supplemented with fish and sunflower oil was due to changes in milk t10-18:1 concentration. However, they did not suggest that t10-18:1 was the causative factor for the decrease in milk fat concentration. Rather, it was concluded that a high concentration of t10-18:1 could be an indicator of rumen conditions favorable for MFD to occur. Furthermore, Lock et al. (2007) recently reported that abomasal infusion of $43 \mathrm{~g} / \mathrm{d}$ of t10-18:1 for $3 \mathrm{~d}$ did not reduce milk fat synthesis in dairy cows.

We used breakpoint analysis in this study as a means to determine the threshold concentration of the respective FA isomer associated with maximum MFD (Figure 3 ). The underlying assumption was that there is a limit to the degree of MFD regardless of the amounts of inhibitory rumen biohydrogenation products taken up by the mammary gland. Indeed, titration studies with t10c12 CLA (Baumgard et al., 2001) and CLA mixtures (Chouinard et al., 1999) suggested a maximal MFD of about 50\% compared with controls.

In this study, the relationship between individual isomers (t6+7+8- to t15-18:1, t7c9 CLA, and t10c12) and milk fat percentage (Figure 3, "a" panels) displayed similar patterns. There was a cluster of data points, especially at low isomer concentrations, where milk fat was variable in relation to isomer concentration. As isomer concentration increased, a linear decrease in milk fat was observed until concentrations of trans-18:1 or CLA reached the breakpoint threshold level. As milk trans-18:1 or CLA isomer concentrations increased beyond the breakpoint, no further depression in milk fat concentration was apparent, regardless of isomer concentration. Using this approach, maximal reduction in milk fat percentage was observed at $0.69,0.86,2.37$, and $1.94 \%$ (\% of FAME) for t6+7+8-, t9-, t10-, and t13+14-18:1, respectively (Figure 3 ). If these isomers caused MFD, then their estimated relative potencies would be greatest for $\mathrm{t} 6+\mathrm{t} 7+\mathrm{t} 8$ - and lowest for t10-18:1. However, the potencies could be related to the preferential synthesis of these trans-18:1 FA in the rumen during MFD.

Individual (Figure 3, panel 3a) and literature-derived (Figure 3, panel 3b) data for t10-18:1 were consistent when the threshold concentrations were similar; 2.37 and $2.52 \%$, respectively. Further, there was greater variation in milk fat responses with t10-18:1 concentrations at $<1.2$ to $1.3 \%$. Recently, Lock et al. (2007) re- ported no change in milk fat with postruminal infusion of $43 \mathrm{~g} / \mathrm{d}$ of t10-18:1 for $3 \mathrm{~d}$ in lactating cows. However, milk t10-18:1 was only $1.11 \%$, well below the suggested threshold concentration and also within the concentration range in which milk fat responses are variable and would be more difficult to detect. Applying the 0.6percentage-unit increase in milk t10-18:1 observed by Lock et al. (2007) to equations shown in Figure 3 (panels $3 \mathrm{a}$ and $3 \mathrm{~b}$ ), the expected decline in fat percentage would have been 0.4 to 0.5 percentage units. Inconsistent milk fat responses that have been observed at low t10-18:1 concentration could be an alternative conclusion vs. a total lack of response to t10-18:1 suggested by Lock et al. (2007).

Postruminal infusion studies with increasing amounts of t10c12 CLA (Baumgard et al., 2000, 2001; Peterson et al., 2002a) showed a curvilinear decline in milk fat, eventually approaching a plateau at maximum MFD. Using literature data obtained from experiments with dietary induced MFD, we showed that the relationships between t6+7+8-, t9-, t11-18:1, and t10c12 CLA and milk fat percentage were linear only. However, maximal t10c12 CLA concentration was much lower than that observed in postruminal infusion studies. Therefore, a possible reason for the lack of a defined breakpoint for t10c12 CLA and other isomers was the inadequate number of observations at high concentrations of these isomers to establish a plateau in milk fat concentration.

As indicated by the slope (Figure 3), the unit decline in milk fat percentage per unit increase in milk trans18:1 isomers was greatest for t6+7+8-18:1 (-2.59) and lowest for t10 (-0.42) suggesting that t6+7+8-18:1 might be more important than t10-18:1 in MFD. Among the CLA isomers, t10c12 CLA was most closely associated with milk fat synthesis (slope, (-15.51; Figure 3, panel 8a), followed by the t7c9 CLA (slope, (-6.55; Figure 3, panel 9a), implying a possible role of t7c9 CLA in MFD. The slopes for these CLA isomers were much greater than those observed for t10-18:1 and other trans-18:1 isomers.

Principal component analysis also showed that t7c9 CLA and t10c12 CLA were the CLA isomers most negatively correlated to milk fat percentage. The importance of t10c12 CLA in MFD has already been established (Baumgard et al., 2000), and Bauman and Griinari (2001) have reported a negative relationship between t10c12 CLA and milk fat concentration. Trans-10, cis12 CLA is also the biohydrogenation precursor for t1018:1 in the rumen (Griinari and Bauman, 1999). Earlier studies (Piperova et al., 2000; Peterson et al., 2003; Loor et al., 2004) have shown that high-concentrate diets supplemented with PUFA can shift ruminal bio- 
hydrogenation toward formation of t10c12 CLA and t10-18:1 and cause MFD.

Possible effects of t7c9 CLA on milk fat synthesis have not been investigated, mainly because of the lack of a pure source for experimental use. Feeding (Piperova et al., 2002) and abomasal infusion (Corl et al., 2002) experiments have provided evidence that $t 7 \mathrm{c} 9$ CLA is almost exclusively produced in the mammary gland via $\mathrm{D} \Delta^{9}$-desaturation of ruminally derived $\mathrm{t} 7$ 18:1. However, it is very difficult to separate t6-, t7-, and t8-18:1 analytically, which prevents quantitation of t7-18:1 conversion to t7c9 CLA.

Shingfield et al. (2003) provided evidence that the proportions of t5-, t10-, t11-, and t12-18:1, and t7c9 CLA were simultaneously and substantially increased in milk of lactating cows fed diets containing fish oil. Pottier et al. (2006) recently reported that concentrations of both t10-18:1 and t7c9 CLA were reduced in milk fat when dietary vitamin E supplementation successfully alleviated MFD. These observations were consistent with the highly positive correlation found between t7c9 CLA and t10-18:1 $(\mathrm{r}=0.61 ; P<0.001)$ in this study (Table 3, Figure 1).

The PCA confirmed earlier reports that the c9t11 CLA (Baumgard et al., 2000) and c11t13 CLA isomers (Perfield et al., 2004) were not associated with changes in milk fat (Figure 1, Table 2). However, in some cases of dietary-induced MFD, an increase in t9c11 CLA has been observed. Abomasal infusion of a CLA mixture enriched in t9c11 CLA suggested that this isomer may be responsible for at least part of the decrease in milk fat production during MFD (Perfield et al., 2005). Examination of milk FA composition responses to fish and sunflower oil-supplemented diets for dairy cows showed a strong correlation between milk fat and t9c11 CLA (Shingfield et al., 2006). Using a dietary strategy to reduce milk fat yield in lactating cows, Roy et al. (2006) found that decreases in fat yield were accompanied by increases in milk t10-18:1 and t9c11-CLA. The authors suggested that these isomers could be directly or indirectly related to antilipogenic activities in the mammary gland.

It could be speculated that configuration of the conjugated double bonds may define specific effects of individual CLA isomers on milk fat synthesis. Perfield et al. (2006) compared abomasal infusion of t10t12 CLA to that of t10c12 CLA and reported that t10t12 CLA did not reduce milk fat yield but significantly altered the desaturase index and milk FA composition in lactating cows. It appears that at least some CLA isomers with trans/cis conjugated double bonds have the ability to decrease milk fat (i.e., t10c12, t9c11, and possibly t7c9), whereas the major cis/trans CLA were not effective (c9t11, c11t13).
In summary, PCA and MA showed that, among trans18:1 isomers, t10-18:1 was the most negatively correlated to milk fat percentage. However, the threshold concentration related to maximum MFD indicated that the relative potency was greatest for $\mathrm{t} 6+7+8$ - and lowest for $t 10-18: 1$. These results suggested that $t 6+7+8-18: 1$ might be more important than t10-18:1 in MFD. Principal component analysis also showed that t10c12 and t7c9 CLA were the isomers most negatively correlated to milk fat percentage, implying a possible role of $\mathrm{t} 7 \mathrm{c} 9$ CLA in MFD. Additional experiments are needed to establish whether t7-18:1 is involved in MFD or that its effects are mediated via the endogenously synthesized t7c9 CLA.

\section{REFERENCES}

AbuGhazaleh, A. A., D. J. Schingoethe, A. R. Hippen, and K. F. Kalscheur. 2003. Milk conjugated linoleic acid response to fish oil supplementation of diets differing in fatty acid profiles. J. Dairy Sci. 86:944-953.

AbuGhazaleh, A. A., D. J. Schingoethe, A. R. Hippen, and K. F. Kalscheur. 2004. Conjugated linoleic acid increases in milk when cows fed fish meal and extruded soybeans for an extended period of time. J. Dairy Sci. 87:1758-1766.

Bauman, D. E., and J. M. Griinari. 2001. Regulation and nutritional manipulation of milk fat: Low-fat milk syndrome. Livest. Prod. Sci. 70:15-29.

Baumgard, L. H., B. A. Corl, D. A. Dwyer, A. Saebo, and D. E. Bauman. 2000. Identification of the conjugated linoleic acid isomer that inhibits milk fat synthesis. Am. J. Physiol. 278:R179-R184.

Baumgard, L. H., J. K. Sangster, and D. E. Bauman. 2001. Milk fat synthesis is progressively reduced by increasing supplemental amounts of trans-10, cis-12 conjugated linoleic acid (CLA). J. Nutr. 131:1764-1769.

Bradford, B. J., and M. S. Allen. 2004. Milk fat responses to a change in diet fermentability vary by production level in dairy cattle. J. Dairy Sci. 87:3800-3807.

Chouinard, P. Y., L. Corneau, A. Saebo, and D. E. Bauman. 1999. Milk yield and composition during abomasal infusion of conjugated linoleic acids in dairy cows. J. Dairy Sci. 82:2737-2745.

Corl, B. A., L. H. Baumgard, J. M. Griinari, P. Delmonte, K. M. Morehouse, M. P. Yurawecz, and D. E. Bauman. 2002. Trans7, cis-9 CLA is synthesized endogenously by $\Delta^{9}$-desaturase in lactating cows. Lipids 37:681-688.

Donovan, D. C., D. J. Schingoethe, R. J. Baer, J. Ryali, A. R. Hippen, and S. T. Franklin. 2000. Influence of dietary fish oil on conjugated linoleic acid and other fatty acids in milk fat from lactating dairy cows. J. Dairy Sci. 83:2620-2628.

Gaynor, P. J., R. A. Erdman, B. B. Teter, J. Sampugna, A. V. Capuco, D. R. Waldo, and M. Hamosh. 1994. Milk fat yield and composition during abomasal infusion of cis or trans octadecenoates in Holstein cows. J. Dairy Sci. 77:157-165.

Griinari, M. J., and D. E. Bauman. 1999. Biosynthesis of conjugated linoleic acid and its incorporation into meat and milk in ruminants. Pages 180-200 in Advances in Conjugated Linoleic Acid Research. M. P. Yurawecz, M. M. Mossoba, J. K. G. Kramer, M. Pariza, and G. J. Nelson, ed. AOCS Press, Champaign, IL.

Griinari, J. M., B. A. Corl, S. H. Lacy, P. Y. Chouinard, K. V. V. Nurmela, and D. E. Bauman. 2000. Conjugated linoleic acid is synthesized endogenously in lactating dairy cows by $\Delta^{9}$-desaturase. J. Nutr. 130:2285-2291.

Griinari, J. M., D. A. Dwyer, M. A. McGuire, D. E. Bauman, D. L. Palmquist, and K. V. V. Nurmela. 1998. Trans-octadecenoic acids and milk fat depression in lactating cows. J. Dairy Sci. $81: 1251-1261$. 
Jolliffe, I. T. 2002. Principal Component Analysis. 2nd ed. SpringerVerlag New York Inc., New York, NY.

Kent, M., and P. Coker. 1992. Vegetation Description and AnalysisA Practical Approach. CRC Press Inc., Boca Raton, FL.

Lock, A. L., C. Tyburczy, D. A. Dwyer, K. J. Havartine, F. Destaillats, Z. Mouloungui, L. Candy, and D. E. Bauman. 2007. Trans-10 octadecenoic acid does not reduce milk fat synthesis in dairy cows. J. Nutr. 137:71-76.

Loor, J. J., A. Ferlay, A. Ollier, M. Doreau, and Y. Chilliard. 2005a. Relationship among trans and conjugated fatty acids and bovine milk fat yield due to dietary concentrate and linseed oil. J. Dairy Sci. 88:726-740.

Loor, J. J., A. Ferlay, A. Ollier, K. Ueda, M. Doreau, and Y. Chilliard. 2005b. High concentrate diets and polyunsaturated oils alter trans and conjugated isomers in bovine rumen, blood, and milk. J. Dairy Sci. 88:3986-3999.

Loor, J. J., and J. H. Herbein. 2003. Reduced fatty acid synthesis and desaturation due to exogenous trans-10, cis-12 CLA in cows fed oleic or linoleic oil. J. Dairy Sci. 86:1354-1369.

Loor, J. J., J. H. Herbein, and C. E. Polan. 2002. Trans 18:1 and 18:2 isomers in blood plasma and milk fat of grazing cows fed a grain supplement containing solvent-extracted or mechanically extracted soybean meal. J. Dairy Sci. 85:1197-1207.

Loor, J. J., F. D. Soriano, X. Lin, J. H. Herbein, and C. E. Polan. 2003. Grazing allowance after the morning or afternoon milking for lactating cows fed a total mixed ration (TMR) enhances vaccenic acid (trans 11-18:1) and rumenic acid (cis-9, trans-11-18:2) in milk fat to different extents. Anim. Feed Sci. Technol. 109:105-119.

Loor, J. J., K. Ueda, A. Ferlay, Y. Chilliard, and M. Doreau. 2004. Biohydrogenation, duodenal flow, and intestinal digestibility of trans fatty acids and conjugated linoleic acids in response to dietary forage: Concentrate ratio and linseed oil in dairy cows. J. Dairy Sci. 87:2472-2485.

Newbold, J. R., K. L. Robertshaw, and H. W. Morris. 1998. Association between concentrations of fat and intermediates of ruminal biohydrogenation in milk of dairy cows. Abstract 224 in Proc. Br. Soc. Anim. Sci. BSAS, Penicuik, Scotland.

Offer, N. W., M. Marsden, J. Dixon, B. K. Speake, and F. E. Thacker. 1999. Effect of dietary fat supplements on levels of n-3 polyunsaturated fatty acids, trans acids and conjugated linoleic acid in bovine milk. Anim. Sci. 69:613-625.

Perfield, J. W., A. L. Lock., A. Sæbo, J. M. Griinari, and D. E. Bauman. 2005. Trans-9, cis-11 conjugated linoleic acid (CLA) reduces milk fat synthesis in lactating dairy cows. J. Dairy Sci. 88(Suppl. 1):211. (Abstr.)

Perfield, J. W., P. Delmonte, A. L. Lock, M. P. Yurawecz, and D. E. Bauman. 2006. Trans-10, trans-12 conjugated linoleic acid does not affect milk fat yield but reduces $\Delta^{9}$ desaturase index in dairy cows. J. Dairy Sci. 89:2559-2566.

Perfield, J. W., A. A. Sæbo, and D. E. Bauman. 2004. Use of conjugated linoleic acid (CLA) enrichments to examine the effects of trans8, cis-10 CLA and cis-11, trans-13 CLA on milk fat synthesis. J. Dairy Sci. 88(Suppl. 1):211. (Abstr.)

Peterson, D. G., L. H. Baumgard, and D. E. Bauman. 2002a. Milk fat response to low doses of trans-10, cis-12 conjugated linoleic acid (CLA). J. Dairy Sci. 85:1764-1766.
Peterson, D. G., J. A. Kelsey, and D. E. Bauman. 2002b. Analysis of variation in cis-9, trans-11 conjugated linoleic acid (CLA) in milk fat of dairy cows. J. Dairy Sci. 85:2164-2172.

Peterson, D. G., E. A. Matitashvili, and D. E. Bauman. 2003. Diet induced milk fat depression in dairy cows results in increased trans-10, cis-12 CLA in milk fat and coordinate suppression of mRNA abundance for mammary enzymes involved in milk fat synthesis. J. Nutr. 133:3098-3102.

Piperova, L. S., U. Moallem, B. B. Teter, J. Sampugna, M. P. Yurawecz, K. M. Morehouse, D. Luchini, and R. A. Erdman. 2004. Changes in milk fat in response to dietary supplementation with calcium salts of trans-18:1 or conjugated linoleic fatty acids in lactating dairy cows. J. Dairy Sci. 87:3836-3844.

Piperova, L. S., J. Sampugna, B. B. Teter, K. F. Kalscheur, M. P. Yurawecz, Y. Ku, K. M. Morehouse, and R. A. Erdman. 2002. Duodenal and milk trans octadecenoic acid and conjugated linoleic acid (CLA) isomers indicate that postabsorptive synthesis is the predominant source of cis-9-containing CLA in lactating dairy cows. J. Nutr. 132:1235-1241.

Piperova, L. S., B. B. Teter, I. Bruckental, J. Sampugna, S. E. Mills, M. P. Yurawecz, J. Fritsche, K. Ku, and R. A. Erdman. 2000. Mammary lipogenic enzyme activity, trans fatty acids and conjugated linoleic acids are altered in lactating dairy cows fed a milk fat depressing diet. J. Nutr. 130:2568-2574.

Pottier, J., M. Focant, C. Debier, G. De Buysser, C. Goffe, E. Mignolet, E. Froldmont, and Y. Larondelle. 2006. Effect of dietary vitamin $\mathrm{E}$ on rumen biohydrogenation pathways and milk fat depression in dairy cows fed high fat diets. J. Dairy Sci. 89:685-692.

Precht, D., H. Hagemeister, W. Kanitz, and J. Voigt. 2002. Milk fat depression and the role of trans and CLA fatty acid isomers by feeding a high fiber diet with calcium soaps of fatty acids in early lactating dairy cows. Milchwissenschaft 57:518-522.

Rindsig, R. B., and L. H. Schultz. 1974. Effect of abomasal infusion of safflower oil or elaidic acid on blood lipids and milk fat in dairy cows. J. Dairy Sci. 57:1459-1466. Romo, G. A., D. P. Casper, R. A. Erdman, and B. B. Teter. 1996. Abomasal infusion of cis or trans fatty acid isomers and energy metabolism of lactating dairy cows. J. Dairy Sci. 79:2005-2015.

Roy, A., A. Ferley, and Y. Chilliard. 2006. Production of butterfat rich in trans 10-C18:1 for use in biomedical studies in rodents. Reprod. Nutr. Dev. 46:211-218.

SAS Institute. 2000. SAS User's Guide: Statistics. Version 8.0 ed. 2000. SAS Inst. Inc., Cary, NC.

Selberg, K. T., A. C. Lowe, C. R. Staples, N. D. Luchini, and L. Badinga. 2004. Production and metabolic responses of periparturient Holstein cows to dietary conjugated linoleic acid and transoctadecenoic acids. J. Dairy Sci. 87:158-168.

Shingfield, K., S. Ahvenjarvi, V. Toivonen, A. Arola, K. V. V. Nurmela, P. Huhtanen, and J. Griinari. 2003. Effect of dietary fish oil on biohydrogenation of fatty acids and milk fatty acid content in cows. Anim. Sci. 77:165-179.

Shingfield, K. J., C. K. Reynolds, G. Hervas, J. M. Griinari, A. S. Grandison, and D. E. Beever. 2006. Examination of the persistency of milk fatty acid composition responses to fish oil and sunflower oil in the diet of dairy cows. J. Dairy Sci. 89:714-732. 